\title{
openheart Ivermectin may be a clinically useful anti-inflammatory agent for late-stage COVID-19
}

James J DiNicolantonio (D) , ${ }^{1}$ Jorge Barroso-Arranda, ${ }^{2}$ Mark McCarty ${ }^{3}$

To cite: DiNicolantonio JJ, Barroso-Arranda J, McCarty M. Ivermectin may be a clinically useful anti-inflammatory agent for late-stage

COVID-19. Open Heart 2020;7:e001350. doi:10.1136/ openhrt-2020-001350

Accepted 25 August 2020

Check for updates

(c) Author(s) (or their employer(s)) 2020. Re-use permitted under CC BY-NC. No commercial re-use. See rights and permissions. Published by BMJ.

${ }^{1}$ Department of Preventive Cardiology, Mid America Heart Insitute, Kansas, Missouri, USA ${ }^{2}$ Clinica Libre de Adicciones, Tijuana, Baja California, Mexico ${ }^{3}$ Catalytic Longevity Foundation, San Diego, California, USA

Correspondence to Dr James J DiNicolantonio; jjdinicol@gmail.com
Ivermectin, on the WHO's List of Essential Medications, has been in clinical use since 1981 as an orally and topically active agent for treating a range of parasitic infections in humans, including river blindness and lymphatic filariasis. It is also widely used in veterinary practice.

Anecdotally, the use of the standard clinical dose of ivermectin, $9 \mathrm{mg}$ once, has been associated with some cases of rapid clinical resolution in severe hospitalised COVID-19; clinical studies evaluating its utility in this regard are underway. Ivermectin is reported to inhibit the proliferation of SARS-CoV-2 in vitro, but the $\mathrm{IC}_{50}$ for this effect, $2 \mu \mathrm{M}$, has been noted to be 35-fold higher than the maximal concentration achieved after the administration of the approved clinical dose $(9 \mathrm{mg})$ to humans, casting doubt on the utility of this agent as an antiviral drug in COVID-19 unless very markedly higher doses are used. ${ }^{12}$ However, drugs blocking viral replication would be expected to be of lesser utility in the context of the late, cytokine storm-associated phase of COVID-19 and anecdotes of ivermectin's success in this disorder pertain to that phase. Hence, consideration should be given to the possibility that ivermectin is acting as an anti-inflammatory in these cases. This prompted us to search the research literature on ivermectin for antiinflammatory actions.

In 2008, Zhang et al studied the impact of ivermectin in mice challenged with intraperitoneal lipopolysaccharide (LPS). They chose a dose of LPS that induced $100 \%$ mortality within 5 days. They then demonstrated that oral ivermectin, administering 2 hours prior to LPS, dose dependently reduced mortality in the LPS-treated mice, with a significant $50 \%$ reduction in mortality being achieved at a $4 \mathrm{mg} / \mathrm{kg}$ dose. ${ }^{3}$ In vitro studies likewise confirmed the ability of this agent to block cytokine production by LPS-challenged macrophages. ${ }^{34}$
When we extrapolate this dose from $20 \mathrm{~g}$ mice to $70 \mathrm{~kg}$ humans, using the two-thirds power of relative body mass (ratio of body surface areas) as a correction factor, $4 \mathrm{mg}$ / $\mathrm{kg}$ in mice corresponds to about $18 \mathrm{mg}$ in humans-double the standard clinical dose. Allometric scaling by the three-fourths power (Kleiber's law) yields a dose of $36 \mathrm{mg} .{ }^{5}$

A study of related interest, published a year later, examined the impact of ivermectin-a group of 16-membered macrocyclic lactone derivatives of which ivermectin is a member-on LPS signalling in the RAW 264.7 murine macrophage-derived cell line. In concentrations ranging from 0.625 to $5 \mathrm{mg} / \mathrm{L}$, ivermectin suppressed activation both of NF-kappaB and the stress-activated MAP kinases JNK and p38. ${ }^{6}$

Moreover, there are two reports that ivermectin, administered either systemically or topically, exerts anti-inflammatory effects in murine models of allergic inflammation (asthma and atopic dermatitis). ${ }^{78}$ The systemic effect was achieved with a $2 \mathrm{mg} / \mathrm{kg}$ dose.

Although it is conceivable that these anti-inflammatory effects of ivermectin are restricted to LPS or toll-like receptor 4 (TLR4) signalling, it may well be the case that it works downstream in this signalling pathway in a way that would be pertinent to other proinflammatory signalling pathways. Moreover, there is reason to suspect that the damage-associated molecular pattern high mobility group box 1 (HMGB1), which is released by dying cells and acts as an agonist for the TLR4 receptor, is a mediator of the lung inflammation associated with COVID$19 .^{9}$ Hence, it is reasonable to suspect that, in doses at or modestly above the standard clinical dose, ivermectin may have important clinical potential for managing disorders associated with life-threatening respiratory distress and cytokine storm-such as advanced COVID-19. Ivermectin may have 
been 'flying under the radar' in this regard during four decades of clinical use.

Two retrospective prepublication reports have appeared in which clinical outcomes were evaluated in hospitalised patients with COVID-19, some of whom received treatment with ivermectin. Rajter et al have reported that, in univariate analysis, mortality in 173 patients receiving one or more doses of ivermectin was significantly lower than in 107 patients not so treated ( $15 \%$ vs $25.2 \%, \mathrm{p}=0.03$ ); after multivariate adjustment for pertinent covariates, this mortality difference was confirmed (OR $0.27, \mathrm{p}=0.03$; HR $0.37, \mathrm{p}=0.03) .{ }^{10}$ Gorial et al examined the mean time of hospital stay in patients who either received or did not receive on admission a standard clinical dose of ivermectin $(200 \mu \mathrm{g} / \mathrm{kg})$ as an adjunct to treatment with hydroxychloroquine/azithromycin. The 16 patients who received ivermectin had hospital stays averaging 7.62 days, notably lower than the average hospital stays of 71 patients not receiving ivermectin (13.22 days; $\mathrm{p}=0.00005$ ). Two patients died in the control group, none in the ivermectin group. ${ }^{11}$ Note that these apparent therapeutic benefits were seen in hospitalised patients, in whom antiviral measures are suspected to be less effective than antiinflammatory measures targeting cytokine storm.

As the impact of ivermectin on antiviral immunity has not been studied, it is unclear whether it would be prudent to withhold its use until later-stage COVID-19.

\section{Contributors All authors contributed to the final manuscript.}

Funding The authors have not declared a specific grant for this research from any funding agency in the public, commercial or not-for-profit sectors.

Competing interests None declared.

Patient consent for publication Not required.
Provenance and peer review Not commissioned; externally peer reviewed.

Open access This is an open access article distributed in accordance with the Creative Commons Attribution Non Commercial (CC BY-NC 4.0) license, which permits others to distribute, remix, adapt, build upon this work non-commercially, and license their derivative works on different terms, provided the original work is properly cited, appropriate credit is given, any changes made indicated, and the use is non-commercial. See: http://creativecommons.org/licenses/by-nc/4.0/.

ORCID iD

James J DiNicolantonio http://orcid.org/0000-0002-7888-1528

\section{REFERENCES}

1 Caly L, Druce JD, Catton MG, et al. The FDA-approved drug ivermectin inhibits the replication of SARS-CoV-2 in vitro. Antiviral Res 2020;178:104787.

2 Schmith VD, Zhou JJ, Lohmer LRL. The Approved dose of ivermectin alone is not the ideal dose for the treatment of COVID-19. Clin Pharmacol Ther 2020. doi:10.1002/cpt.1889. [Epub ahead of print: 07 May 2020].

3 Zhang X, Song Y, Ci X, et al. Ivermectin inhibits LPS-induced production of inflammatory cytokines and improves LPS-induced survival in mice. Inflamm Res 2008:57:524-9.

4 Zhang $\mathrm{X}$, Song $\mathrm{Y}$, Xiong $\mathrm{H}$, et al. Inhibitory effects of ivermectin on nitric oxide and prostaglandin E2 production in LPS-stimulated RAW 264.7 macrophages. Int Immunopharmacol 2009;9:354-9.

5 Capellini I, Venditti C, Barton RA. Phylogeny and metabolic scaling in mammals. Ecology 2010;91:2783-93.

$6 \mathrm{Ci} \mathrm{X}, \mathrm{Li} \mathrm{H}$, Yu Q, et al. Avermectin exerts anti-inflammatory effect by downregulating the nuclear transcription factor kappa-B and mitogen-activated protein kinase activation pathway. Fundam Clin Pharmacol 2009;23:449-55.

7 Yan S, Ci X, Chen N, et al. Anti-Inflammatory effects of ivermectin in mouse model of allergic asthma. Inflamm Res 2011;60:589-96.

8 Ventre $\mathrm{E}$, Rozières $\mathrm{A}$, Lenief $\mathrm{V}$, et al. Topical ivermectin improves allergic skin inflammation. Allergy 2017;72:1212-21.

9 Andersson U, Ottestad W, Tracey KJ. Extracellular HMGB1: a therapeutic target in severe pulmonary inflammation including COVID-19? Mol Med 2020;26:42.

10 Rajter.J.C. SM, Fatteh N, Vogel F, et al. Icon (ivermectin Ni COvid nineteen) study: use of ivermectin is associated with lower mortality in hospitalized patients with COVID19. medRxiv 2020.

11 Gorial FI, Mashhadani S, Sayaly HM, et al. Effectiveness of ivermectin as add-on therapy in COVID-19 management (pilot trial). medRxiv 2020. 


\section{Correction: Ivermectin may be a clinically useful anti- inflammatory agent for late-stage COVID-19}

DiNicolantonio JJ, Barroso J, McCarty M. Ivermectin may be a clinically useful antiinflammatory agent for late-stage COVID-19. Open Heart 2020;7:e001350. 10.1136/ openhrt-2020-001350.

Author name Jorge Barroso has been corrected to Jorge Barroso-Aranda.

Open access This is an open access article distributed in accordance with the Creative Commons Attribution Non Commercial (CC BY-NC 4.0) license, which permits others to distribute, remix, adapt, build upon this work non-commercially, and license their derivative works on different terms, provided the original work is properly cited, appropriate credit is given, any changes made indicated, and the use is non-commercial. See: http://creativecommons.org/licenses/by-nc/4.0/.

C Author(s) (or their employer(s)) 2020. Re-use permitted under CC BY-NC. No commercial re-use. See rights and permissions. Published by BMJ.

Open Heart 2020;7:e001350corr1. doi:10.1136/openhrt-2020-001350corr1

A) Check for updates 